\title{
Foreign Investors and Global Integration of Emerging Indian Equity Market
}

\author{
Sunil S. Poshakwale ${ }^{\mathrm{a}, *}$ and Chandra Thapa ${ }^{\mathrm{b}}$ \\ ${ }^{a, b}$ Centre for Research in Economics and Finance, School of Management, Cranfield University England, \\ MK43 OAL
}

\begin{abstract}
This paper examines the influence of foreign investors in explaining short and long-run relationship of the emerging Indian equity market with global equity markets. Using daily return series and equity portfolio investments made by foreign institutional investors, we find that the trading activities of foreign investors contain significant information in explaining short and long-run comovements of the Indian market with global equity markets. The global linkages have become pronounced particularly in the second half of the sample period. We conclude that the rapid growth in the flow of foreign equity portfolio investments is leading to greater integration of the Indian equity market with global markets. The increased global integration of the Indian market would not only reduce diversification benefits but will also make the Indian market more susceptible to global shocks, as has been witnessed by significant losses suffered by investors in the Indian market following the sub-prime crisis.
\end{abstract}

JEL classification: G11, G15, F12

Key words: Foreign portfolio investments, Emerging Indian stock market, Sub-prime crisis, VEC, and Cointegration.

* Corresponding Author:

Email address:sunil.poshakwale@cranfield.ac.uk (Sunil Poshakwale) 


\section{Introduction}

In the last decade or so, foreign investors' interest in the emerging Indian equity market has been growing because of the continuation of the economic liberalisation process and impressive performance of the Indian economy. India's economic growth has been fuelled by strong macroeconomic outcomes, improving infrastructure, growing outsourcing activities by western companies in India and increasing consumption appetite of India's fast-growing, large middle class population. The surge in the level of foreign investors' interest in more recent past is largely attributed to the consistent GDP growth of around 8.5 percent. According to latest estimates, India's GDP has exceeded the US\$ one trillion mark and in terms of growth, it is the second fastest growing economy in the world after China (Adhikari, 2007). Further, India's competitive position in the Switzerland based International Institute of Management Development (IIMD) ranking has also remarkably improved by ten places to $29^{\text {th }}$ position in 2006 from $39^{\text {th }}$ in 2005. These rankings of IIMD are based on 312 criteria, which include government efficiency, business efficiency, infrastructure, and economic performance (Chaze, 2006). Thus, as a result of excellent economic growth coupled with further easing of foreign investment regulations and the impressive performance of the Indian stock market since 2001, foreign portfolio investments have been increasing and had reached a record level of US\$49 billion by the end of December 2006.

The growth in foreign equity portfolio investments in emerging markets like India has significant implications. Historically, one of the main motivations for investing in emerging markets like India was significant diversification benefits it offered to international investors because it was viewed as a segmented market (Chatrath et al., 1996). However, if the present magnitude and pace of foreign investments are sustained over time then emerging markets like India may not remain segmented. This will not only reduce international portfolio diversification benefits but will also make the Indian market more vulnerable to the global shocks. There is evidence which suggests that foreign investors have short-term investment interest and at the sign of slightest trouble, the foreign capital tends to leave at a much greater pace than the pace at which it arrives in emerging markets (Bekaert, Harvey and Lumsdaine, 2002). Further, the massive losses experienced by investors following the sub-prime crisis since August 2007 makes it all the more critical that the globalisation paradigm is re-examined using a case study of India since it is one of the few emerging markets at the forefront of the global economic growth. Thus it is both topical as well as critical for academics and policy makers to have a greater understanding of the role and influence of foreign investors' activities. This paper addresses this key issue by providing empirical evidence on the impact of foreign portfolio flows on the shortrun and long-run behaviour of the Indian stock market.

There is extant literature that has shown that equity markets around the world have become more integrated and globally, stock price movements show greater degree of comovements (see for example, Hamao et al., 1990, Becker et al 1990, Lin et al.1994, Lognin and Solnik, 2001, Hsin, 2004, Chelley-Steeley, 2005, and Syriopoulos, 2007). One of the common conclusions of the aforementioned studies is that the US and UK stock markets lead market comovements because they transmit shocks not only to their developed counterparts but also to the emerging equity markets in developing countries. Dungey et al. (2004) reports that equity markets in Australia are affected by shocks common to all other markets around the world. They find that 
the US market plays a significant role in explaining the Australian equity market's movement and Australia's domestic output has a very small impact on its own equity market which seems to diminish in the long run. Richards (2005) finds similar and conclude that foreign investors and conditions external to the local markets have impact greater than those reported in the earlier studies. In another study involving stock markets of the US, Europe, and Asia-Pacific region, Hsin (2004) reports evidence consistent with previous findings of strong linkages and transmission effects among the regional participants in Europe, such as Germany, Britain and France and Asia-Pacific markets of Japan, Australia, Hong Kong, and Singapore. On the other hand, Soydemir (2000) investigates the pattern of comovements between developed and emerging market economies using economic fundamentals and trade linkages. He concludes that Mexico and USA show stronger linkages whereas Argentina and Brazil reveal a weaker association and attributes this variation to trade flow differences. However, Soydemir does not examine the direct influence of trading activities of foreign investors.

Thus there is little or no research that empirically examines the impact that foreign investors are exerting on the integration of emerging equity markets since Errunza (2001) suggests that an increase in foreign investment augments market integration further supplementing information to explain equity market integration. Further, Bekaert et al. (2002) have shown that consistent with the price pressure hypothesis, information incorporated in foreign equity flows increases emerging market returns. In another related study on the long run equilibrium relationship amongst four central European emerging markets and developed markets of Germany and the UK, Syriopoulos (2007) conjunctures that increase in inflow of foreign portfolio investments may have been a significant factor for the observed long run equilibrium relationship amongst emerging and developed markets. However, he does not explicitly examine this relationship. Similarly, though Lane and Milesi-Ferretti (2003) have investigated the impact of foreign portfolio and direct investments on financial integration for a sample of industrialized countries, there are relatively fewer studies involving emerging markets and even fewer on the emerging Indian equity market. For example, Sharma (2003) investigates the impact of foreign investment on India's export performance and finds that foreign investment does not statistically affect the export performance. Lamba (2005) using data from July 1997 to December 2003 reports that the Indian market is becoming increasingly influenced by the US and UK equity markets and their impact have been persistent since the September 11 attack in the US. However, research that investigates the direct influence of trading activities of foreign investors on the integration of the emerging Indian equity market with global equity market is lacking.

This paper fulfils an important gap in the literature by examining the influence of foreign portfolio investments in explaining the short and long-run relationship of the emerging Indian equity market with global equity markets. Using daily return series and net foreign portfolio investments data, we find that the growing trading activities of foreign investors contain significant information in explaining short-run dynamics and long-run comovements. We conclude that the rapid growth in the flow of foreign equity portfolio investments is leading to greater integration of the Indian equity market with global markets. Analysis of the short-term dynamics suggests that in future, the Indian market may become more vulnerable to global 
shocks and, as a consequence, changes in global economic conditions and/or events may have a destabilizing effect on the Indian equity market. ${ }^{1}$

The paper is organized as follows. The following section provides the data and methodology. Section 3 documents empirical findings, and Section 4 concludes the paper.

\section{Data and Methodology}

\subsection{Data}

The significant increase in foreign investments has followed an impressive economic growth and performance of the Indian economy (see, Panel A of Table 1). The, most notable fact is that more than half of the investment, approximately US\$28 billion has been received in 2004 and 2005. The Mumbai Stock Exchange, which is considered as the barometer of the stock markets in India has shown significant increase in capitalisation and turnover (see, Panel B of Table 1). This is also reflected in the strong performance of the Indian equity market. In particular, significant growth in the Indian stock market has occurred since 2004. Also, the MSCI Indian index has outperformed the MSCI World index which represents 23 developed markets (see Figure 1).

\section{Insert Table 1 here}

Insert Figure 1 here

We use daily data in our analysis for a sample period of six years beginning 1 January 2001 to 15 January 2007. Daily returns are calculated from the MSCI Indian index denominated in US\$ and the MSCI world total return index which is a composite index of 23 developed markets. Since Net Foreign Equity Investment (NFEI) data represents total of foreign portfolio investments from all countries, we use MSCI world index as proxy for global equity returns. The MSCI indexes have been obtained from DataStream International. Net daily foreign equity portfolio investment data is obtained from the Securities Exchange Board of India (SEBI) as available on the CNBC's Moneycontrol.com website. We split the total sample into two subperiods because the trading activities of foreign institutional investors in the Indian equity market have substantially increased since early 2004. ${ }^{2}$ This is evident from Figure 2 which shows a

\footnotetext{
${ }_{1}$ In hindsight, this has turned out be true. At the time of writing, the Indian equity markets had been extremely volatile and as result of large scale withdrawal of investments by foreign institutional investors following the sub-prime crisis, the Bombay Stock Exchange (BSE) Sensex index suffered biggest weekly fall in 18 years on October 12, 2008.

${ }^{2}$ We also test for any structural break in the series of cumulative NFEI. One of the most appropriate tests for identifying the structural break in the single series is the unit root test developed by Zivot and Andrews (1992). Their unit root test involves three different models, the first allows one time change in level (intercept) of the series, the second, allows for a one time change in the slope of the series and finally the third combines changes in the level and the slope of the trend function (see, Zivot and Andrews, 1992 for more details). Since our objective is to test the structural break in the mean value (intercept), we test for the structural break using the first model and identify the date for structural break as 17 May 2004. As such, our selection of sub samples also justifies Zivot and Andrews' structural break test. We would like to thank the anonymous referee for this valuable comment.
} 
significant rise in the net daily foreign equity investment from 2004 onwards. The average daily net foreign equity investment rose to US\$34.29 millions during the period 2004-07 from US\$13.26 millions for the period 2001-03.

Insert Figure 2 here

\subsection{Methodology}

We take a non-structural approach for investigating the impact of foreign investment on the short and long-run dynamics of Indian equity market with the global markets. Use of a nonstructural approach is advocated by Bekaert and Harvey (2000) who suggest that due to lack of theoretical basis, non-structural approach should be preferred in conducting portfolio flow studies. $^{3}$

\subsubsection{Cointegration}

We examine the long-run relationship between Indian and global equity markets using VAR analysis proposed by Johansen (1988) and Johansen and Juselius (1990). We follow JohansenJuselius (JJ) because their approach is considered superior to the regression-based approach suggested by Engle and Granger in 1987 (Cheung and Lai, 1993) ${ }^{4}$. Another reason for using the $\mathrm{JJ}$ approach is that it utilizes the maximum likelihood estimates and allows testing and estimation of more than one cointegrating vector in the multivariate system without requiring a specific variable to be normalized. This way, the JJ tests overcome the problem of carrying over the errors from the first step into the second step commonly encountered in Engle and Granger's (1987) approach to cointegration. Further, Johansen's method is independent of the choice of the endogenous variable within a vector autoregression (VAR) framework.

The general VAR equation can be rewritten as,

$$
\Delta y_{t}=\Pi y_{t-1}+\sum_{i=1}^{p-1} \Gamma_{i} \Delta y_{t-i}+B x_{t}+\varepsilon_{t}
$$

(1)

Where:

$$
\begin{aligned}
& \Pi=\sum_{i=1}^{p} A_{i}-I \text {, and } \\
& \Gamma_{i}=-\sum_{j=i+1}^{p} A_{j}
\end{aligned}
$$

${ }^{3}$ A non structural approach is also supported by Tesar and Werner (1995) who find that even in the relatively open markets, the substantial increase in cross-border flows do not comply with theoretical foundations of optimal portfolio theory due to home bias effects.

\footnotetext{
${ }^{4}$ The Johansen-Juselius procedure resolves the problem of endogeneity in that we do not need to normalise the cointegrating vector on one of the variables as required in the Engle and Granger (EG) test.
} 
Since our objective is to investigate the long-run relationship, we will focus on the elements of matrix $\Pi$. If vector $y$ contains $\mathrm{m}$ variables, matrix $\Pi$ will be of the order $\mathrm{m} x \mathrm{~m}$, with a maximum possible rank of $m$ (or full rank). Equation (1), except for the $\Pi y_{t-k}$ term, is in the form of the traditional VAR with first difference. The $\Pi$ term determines whether the system of equations is cointegrated, i.e., whether a long-run equilibrium relationship exists. The feature to note is that the rank of matrix $\Pi$ is equal to the number of independent cointegrating vectors. If rank of matrix $\Pi=0$, the matrix is null, i.e., all the elements in this matrix are zero, which implies no cointegration and the error correction mechanism, $\Pi y_{t-k}$, therefore, does not exist. In determining the rank of matrix $\Pi$ (number of cointegrating vectors), we calculate the characteristic roots or

eigenvalues, $\hat{\lambda}_{i}$ of $\Pi$. Johansen (1988) and Johansen and Juselius (1990) propose trace $\left(\lambda_{\text {trace }}\right)$ and maximum eigenvalue $\left(\lambda_{\max }\right)$ test statistics to establish whether the characteristic roots are significantly different from zero. The likelihood ratio statistic for the trace test $\left(\lambda_{\text {trace }}\right)$ is:

$$
\lambda_{\text {trace }}(r)=-T \sum_{i=r+1}^{m} \ln \left(1-\hat{\lambda}_{i}\right)
$$

Where $\hat{\lambda}_{i}=$ the estimated values of the characteristic roots (also known as eigenvalues) obtained from the estimated $\Pi$ matrix. The null hypothesis to be tested is that the number of cointegrating vectors is less than or equal to $r$ against the alternative hypothesis that the number of cointegrating vectors is more than $r$. For example the null hypothesis $r \leq 0$ against alternative $r=1, r \leq 1$ against alternative $r=2$, and so forth. The computed values of $\lambda_{\text {trace }}$ statistics are evaluated using the critical values provided by Osterwarld-Lenum (1992). The optimal system lag length is determined by using the Schwarz Information Criteria (SIC). Specifically, the appropriate number of lags for each variable is obtained by computing the SIC over different lag schemes in the range from 1 to 20 and by choosing the number of lags that yields the lowest value for the SIC.

\subsubsection{Error Correction Representations}

In cases where we find cointegration, we employ the Vector Error Correction Model (VECM). VECM provides an effective way for analysing the speed with which the error is corrected in the observed long-run relationship. If variables are cointegrated, they converge in the long run despite showing deviations in the short run. VECM examines this equilibrium relationship and shows the feedback mechanism via the error correction term. VECM also provides a mechanism to identify the magnitude and length of information being transmitted from one series to another through the system, referred as the Variance Decomposition (VD) and the Impulse Response Function (IRF) respectively. The VECM is employed on first difference of I(1) variables as shown below.

$$
\Delta y_{t-1}=\beta_{1} \Delta x_{t-i}+\beta_{2} \Delta w_{t-i}+\beta_{3} z_{t-1}+\mu_{t}
$$

The above is a three variables model with $y$ and $x$ being return series and $w$ being the cumulative net equity investment series. The cointegrating vector $\mathrm{z}_{\mathrm{t}-1}$ is the error correction term which will be I (0) if the series in their level form have long-run relationship. This term corrects 
the short-run deviations and facilitates long-run convergence. $\beta_{3}$ measures the speed of adjustment of the short term deviations back into long run equilibrium. The other two coefficients $\left(\beta_{1}, \beta_{2}\right)$ exhibit short-run relationship.

\subsubsection{Granger Causality}

The short-run dynamics are examined using the Granger causality between the endogenous variables in the following way:

$$
\begin{aligned}
& R_{\mathrm{y}, \mathrm{t}}=\mathrm{a}+\sum_{i=1}^{n} \beta_{\mathrm{i}} R_{\mathrm{y}, \mathrm{t}-\mathrm{i}}+\sum_{i=1}^{n} \gamma_{\mathrm{i}} R_{\mathrm{x}, \mathrm{t}-\mathrm{i}}+\varepsilon_{\mathrm{t}} \\
& R_{\mathrm{x}, \mathrm{t}}=\mathrm{a}+\sum_{i=1}^{n} \delta_{\mathrm{i}} R_{\mathrm{x}, \mathrm{t}-\mathrm{i}}+\sum_{i=1}^{n} \zeta_{\mathrm{i}} R_{\mathrm{y}, \mathrm{t}-\mathrm{l}}+\mathrm{u}_{\mathrm{t}}
\end{aligned}
$$

Where $\mathrm{R}_{\mathrm{y}, \mathrm{t}}$ and $\mathrm{R}_{\mathrm{x}, \mathrm{t}}$ are the returns of index $\mathrm{y}$ and $\mathrm{x}$ at time $\mathrm{t}$ accordingly.

In the above regressions we examine whether the coefficients $\gamma_{\mathrm{i}}$ and $\zeta_{\mathrm{i}}$ are equal to zero using the standard $\mathrm{F}$ test. If $\gamma_{\mathrm{i}}$, and $\zeta_{\mathrm{i}}$ coefficients are different from zero then we conclude that there is a bi-directional causality between and $\mathrm{R}_{\mathrm{y}, \mathrm{t}}$ and $\mathrm{R}_{\mathrm{x}, \mathrm{t}}$. Alternatively, if both coefficients are found to be equal to zero, then we conclude that there is no causality. Finally, in equation (6) $R_{y, t}$ Granger causes $R_{x, t}$ if $\gamma_{i}=0$ for $i=1,2, \ldots n$. Similarly, in (7) causality implies that $R_{x, t}$ Granger causes $R_{y, t}$, provided that $\zeta_{\mathrm{i}} \neq 0$ for $\mathrm{i}=1,2, \ldots \mathrm{n}$. Our test uses daily foreign equity investment data to test the causality with returns.

\subsubsection{Impulse Response Function}

Impulse Response Function (IRF) explains how a unit shock in one variable in isolation of the others, affects the movement in other variables. In each of the equation one unit shock is applied to detect changes in the VAR system over time by representing the VAR as VMA (Vector Moving Average):

$$
R i, t=b_{11}^{0} \varepsilon_{i, t}+b_{11}^{1} \varepsilon_{1, t-1}+b_{12}^{1} \varepsilon_{2, t-1}+\ldots \ldots
$$

Where, $b_{i j}$ are unit normalized innovation coefficients of impulse response function following the normalization by the Cholesky factor (see Diebold, 2004) and $b_{11}^{0}$ is the simultaneous effect of a unit shock to $\varepsilon_{i, t}$. The contemporaneous innovation is stated in standard deviation form and have non-unit coefficient in contrast to its unit coefficient in equation.

\subsubsection{Variance Decomposition}

Previous research has shown that variance decomposition analysis is an effective way to examine the dynamic interactions amongst economic time series (Sims, 1980). Whilst impulse response function traces the effects of shocks amongst the endogenous variables, variance decomposition enables further analysis by separating the $h$-step error variations. The variance decomposition thus offers greater insights about the relative significance of each random 
innovation that affects the variables in VAR. Decomposing the variance offers slightly different perspective on the relationship of the identified variables since it shows what proportion of the variance is due to a shock in its own lags against the shocks in other variables. A shock to variable $i$ will not only affect its own future outcomes but will also be transmitted to other variables.

\section{Empirical Results}

The descriptive statistics for the whole sample as well as two sub-periods are given in Table 2. Average daily returns from the Indian equity market (0.097) are significantly higher than the MSCI world equity index (0.024) for the full sample period. The average returns are also higher for the two sub-periods. However, higher returns from the Indian market are associated with higher volatility. The standard deviation for the Indian market returns is higher (1.430) as compared to the standard deviation of global equity market returns $(0.863)$ for the full sample period. We will expect the volatility to be higher in the second sub-period given that the previous literature has shown that foreign portfolio investments tend to be volatile. Our findings confirm this as the reported standard deviation for second sub-period (1.498) is higher than the standard deviation in the first sub-period (1.357). The average Net Foreign Equity Investment (NFEI) average is substantially higher in the second sub-period rising by over $150 \%$.

Insert Table 2 here

\subsection{Long Run Relationship}

The Augmented Dickey-Fuller Statistics presented in Table 3 confirm that all series in their level form are non-stationery since the ADF statistics are not statistically significant. However, the series in their first difference are stationery with $\mathrm{I}(0)$. The $\mathrm{JJ}$ cointegration model (equation 1 ) is then applied on the log of the level series for the sub sample periods. The findings are presented in Table 4. Panel A reports results of cointegration analysis involving the Indian and World indexes for the first sub-period (2001-2003). Figures in Panel A show that both Trace as well as the Eigenvalue statistics are lower than their critical values suggesting lack of a long term relationship between the Indian and the world equity markets. However for the second sample period, the Trace and Eigenvalue statistics are highly significant confirming that at least one cointegrating vector exists. The results are consistent with the increased foreign investment activity in the second sub-period, 2004-2007. This is further corroborated by the results presented in Panel $\mathrm{C}$ and Panel $\mathrm{E}$ where we find that by including NFEI series in the cointegration analysis at least one cointegrating vector is found for the first sample period and at least two cointegrating vectors are found in the second sample period. However, presence of a cointegrating vector in the first sample period (Panel C) is attributed to long-run equilibrium relationship between the world equity markets and portfolio investments as reported in Panel D. Thus identification of an additional cointegrating vector in the second sample period (Panel E) suggests that increasing trading activity of foreign investors (NFEI) appears to be playing a role in the integration of the Indian equity market with the global equity markets. Consistent with the evidence reported in the previous literature, we find that that the Indian equity market shows greater degree of integration in the second sub-period when the foreign portfolio investments were significantly higher. The growing global integration will make the Indian market more 
susceptible to global shocks, as has been witnessed by significant losses suffered by investors in the Indian market following sub-prime crisis.

Insert Table 3 here

Insert Table 4 here

\subsection{VEC Estimation}

Since as expected, cointegrating relationships are found only in the second sample, the error correction model is employed on the first differenced data for sub-period 2004-2007. The error correction model is employed for three primary purposes. The first is to detect the causality running from one series to another through the system, second is to analyze the speed of adjustment, and the final one is to detect the magnitude and length of the impact of shocks in one variable as a consequence of the shocks in another variable. Results of the VEC estimations are reported in Tables $5 \& 6$. The findings show that world market returns not only influence NFEI but also equity returns from the Indian market. This is consistent with the existing literature which reports that the developed markets transmit information to other markets (Dungey 2004). The significant Error Correction Term (ECT) statistic of -8.73 indicates that response from the developed market adjusts to the deviations observed in the equilibrium relationship with the Indian equity markets as reported in Table 4. The F-test statistic for NFEI is also statistically significant and confirms that foreign investors play a significant part in explaining Indian equity market returns. This is consistent with findings reported by Richards (2005) for other Asian emerging markets. The statistically significant ECM results further support the evidence of cointegration results reported earlier.

\section{Insert Table 5 here}

\subsubsection{Variance Decomposition}

Variance decomposition helps in investigating the short-run magnitude of shocks transmitted through the system. We use a three variables future error variance decomposition analysis to detect the short-run dynamics. The ordering of the series is based on the market value of series in US\$ terms and therefore it stands as World, India and NFEI. The innovation account analysis is presented for day 1 , day 5 to day 40 . We expect that with greater levels of foreign portfolio investments, we will find greater transmission of shocks from global markets to Indian markets. Results in Table 6 show that the forecast variance of world equity market returns is mainly explained by the shocks in its own variance and by innovations in the Indian market. Innovations in NFEI has relatively little impact. On the other hand, we find that innovations in variance of world equity returns significantly account for the future error variance in Indian returns and its influence increases with increase in number of lags. As expected, the Indian market is significantly influenced by the information and shocks arising in the global equity markets. The innovations in the variance of NFEI have relatively smaller influence on the forecast variance of Indian market returns. Finally, in case of NFEI, innovations in variance are mainly explained by its own previous shocks.

Insert Table 6 here 


\subsubsection{Impulse Response Function}

The impulse response function (IRF) aids in examining the responsiveness of a variable to one unit of standard deviation innovation in another variable. If the response is permanent then the impact reverts back in the equilibrium system but if it's just transitory, then the effect fades away quickly. Figure 3, provides IRF for innovations in world equity returns. Once again, as before, we expect that Indian equity markets will show greater responsiveness to global information following the increased global integration of the Indian market. The result shows that the response of returns in the world equity markets is primarily explained by its own shocks with a very short time horizon. There is some evidence of information being transmitted from the Indian market to the world markets for a couple days, however the effect is short lived. The effect of NFEI on world equity markets returns is negligible. The response in the Indian market to innovations in global market returns, as reported in Figure 4 shows that Indian market returns significantly respond to innovations in global equity market returns. Although the impact is short term, it seems to have a permanent effect lending support to the reported equilibrium relationship in Table 4. Further, the Indian equity market returns also respond to innovations in NFEIs suggesting the growing influence of foreign investors. The innovations in NFEI in Figure 5 show that NFEI responds instantaneously to the innovations in world and Indian returns. More significantly, NFEI tends to react more to its own innovations confirming the positive feedback effects in investment activities of foreign institutional investors documented by previous research (see, Froot, et al., 2001).

Insert Fig 3 here

Insert Fig 4 here

Insert Fig 5 here

\section{Conclusions}

A significant increase in foreign portfolio investments in emerging markets in general in Indian equity markets in particular is a matter of concern to the policy makers in developing countries. Indian stock market's excellent performance since 2001 together with impressive economic growth and easing of foreign investment regulations economy has attracted significant foreign portfolio investments. It is expected that increased foreign portfolio investments will increase the global linkages and, as a consequence, exposing the Indian equity market to become more vulnerable to global shocks.

This paper provides empirical evidence of role and the influence of foreign institutional portfolio investments in explaining short and long-run behaviour of the emerging Indian equity market. To the best of our knowledge, this is the first study that provides evidence on the influence of foreign investors in the Indian equity market. Using daily returns from the MSCI Indian equity index, MSCI global equity index, and portfolio investments made by foreign institutional investors and employing a variety of econometric tests, we find that the growing trading activities of foreign investors contain significant information in explaining short-run dynamics and long-run comovements of the Indian equity market with global equity markets. The findings of this paper have significant theoretical and practical implications. Theoretically, 
the significant response of the Indian equity market returns to global shocks suggests that in pricing Indian assets, an appropriate asset pricing model would need to include global factors. Practically, increased global integration of the Indian market would not only reduce diversification benefits but will also make the Indian market more susceptible to global shocks, as has been witnessed by significant losses suffered by investors in the Indian market following the sub-prime crisis. 


\section{References}

Adhirkari, A (2007). The race to $\$ 10$ Trillion: How long will it take for Indian GDP to multiply 10 times from its current level?, Business Today, May 20, 21- 46

Becker, K. G., Finnerty, J. E. and Gupta, M. (1990). The Intertemporal Relation between the U.S. and Japanese Stock Markets. The Journal of Finance, 45 (4), 1297 - 1306

Bekaert, G. and Harvey, C. R. (2000). Foreign speculators and emerging equity markets. The Journal of Finance, 55(2), 565 - 613

Bekaert, G., Harvey, C. R. and Lumsdaine, R. L. (2002). The dynamics of emerging market equity flows. Journal of International Money and Finance, 21 (3), 295 - 350

Chatrath, A., Ramchander, S and Song, F (1996). Benefits from Portfolio Diversification into the Indian Equity Market. American Business Review, Jan, 1 - 10

Chaze, A (2006). Investors push Indian markets to an all-time high, Global Finance, 20(6), p-1

Chelley-Steeley, P. L. (2005). Modeling equity market integration using smooth transition analysis: A study of Eastern European stock markets. Journal of International Money and Finance, 24(5), 818 831

Cheung, Y. and Lai, K. S. (1993). A fractional cointegration analysis of purchasing power parity. Journal of Business \& Economic Statistics, 11(1), 103 - 223

Diebold, F.X (2004). Elements of Forecasting, 3rd Ed, South Western.

Dungey, M., Fry, R. and Martin, V. L. (2004). Identification of common and idiosyncratic shocks in real equity prices: Australia, 1982-2002. Global Finance Journal, 15(1), 81 - 102

Engle, R.F and Granger, C.W.J (1987). Co-integration and error correction: Representation, estimation and testing. Econometrica, 55, 251-276

Errunza, V. (2001). Foreign portfolio equity investments, financial liberalization, and economic development. Review of International Economics, 9(4), 703 - 726

Froot, K. A, O'connel, P.G.J and Seasholes, M.S (2001). The portfolio flows of international investor. Journal of Financial Economics, 59, 151 - 193

Hamao, Y., Masulis, R. W. and Ng, V. (1990). Correlations in Price Changes and Volatility across International Stock Markets. The Review of Financial Studies, 3 (2), 281 - 307

Hsin, C. (2004). A multilateral approach to examining the comovements among major world equity markets. International Review of Financial Analysis, 13 (4), 433 - 462

Johansen, S. (1988). Statistical analysis of cointegration vectors in Gaussian vector autoregressive models. Econometrica, 59, 1551-1580 
Johansen, S. and Juselius, K. (1990). Maximum Likelihood Estimation and Inference on Cointegration With Applications to the Demand for Money. Oxford Bulletin of Economics and Statistics, 52 (2), $169-210$

Lamba, A. S. (2005). An Analysis of the Short- and Long-Run Relationships Between South Asian and Developed Equity Markets. International Journal of Business, 10 (4), 383 - 402

Lane, P. R. and Milesi-Ferretti, G. M. (2003). International financial integration. IMF Staff Papers, 50, 82 $-113$

Lin, W., Engle, R. F. and Ito, T. (1994). Do Bulls and Bears Move across Borders? International Transmission of Stock Returns and Volatility. The Review of Financial Studies (1986-1998), 7(3), $507-538$

Longin, F. and Solnik, B. (2001). Extreme correlation of international equity markets. The Journal of Finance, 56(2), 649 - 676

Osterwal-Lenum, M. (1992). A note with quartiles as the asymptotic distribution of the maximum likelihood cointegration rank test statistic. Oxford bulletin of Economics and Statistics, 54, 461-472

Richards, A. (2005). Big fish in small ponds: The trading behaviour and price impact of foreign investors in Asian Equity Markets. Journal of Financial and Quantitative Analysis, 40(1), 1-27

Sharma, K (2003). Factors determining India's export performance. Journal of Asian Economics, 14(3), $435-446$

Sims, C. A. (1980). Macroeconomics and reality, Econometric. 48, 1- 49.

Soydemir, G. (2000). International transmission mechanism of stock market movements: Evidence from emerging equity markets. Journal of Forecasting, 19 (3), 149 - 176

Syriopoulos, T. (2007). Dynamic Linkage between Emerging European and Developed Stock Markets: Has the EMU any impact? International Review of Financial Analysis, 16, 41- 60

Tesar, L. L and Werner, I. M. (1995). Home bias and high turnover. Journal of International Money and Finance. 14 (4), $467-493$

Zivot, E. and Andrews, Donald W.K. (1992), 'Further Evidence on the Great Crash, the Oil-Price Shock, and the Unit-Root Hypothesis', Journal of Business \& Economic Statistics, 10(3), 251-270. 
Table No. 1: Panel A

Basic Economic Indicators of India

\begin{tabular}{llllll}
\hline & $2002(\mathrm{a})$ & $2003(\mathrm{a})$ & $2004(\mathrm{a})$ & $2005(\mathrm{a})$ & $2006(\mathrm{~b})$ \\
GDP (US\$ bn) & 508 & 596 & 693 & 806 & 904 \\
Real GDP growth (\%)C & 3.60 & 8.30 & 8.50 & 8.50 & 9.20 \\
Exports of goods (US\$ m) & 51,153 & 60,895 & 77,939 & 103,410 & 121,671 \\
Imports of goods (US\$ m) & $(60,723)$ & $(75,537)$ & $(105,975)$ & $(149,139)$ & $(186,872)$ \\
FX reserves excl gold (US\$ m) & 67,666 & 98,938 & 126,593 & 131,924 & 170,738
\end{tabular}

(a) Actual. (b) Economist Intelligence Unit estimates. (c) Fiscal year (beginning April $1^{\text {st }}$ of year indicated); seasonally adjusted; includes statistical discrepancy.

Source: Economic Intelligence Unit, 21 May, 2007

Panel B

S\&P/IFC Indian Equity Market Data Summary

\begin{tabular}{|c|c|c|c|c|c|c|}
\hline & 2001 & 2002 & 2003 & 2004 & 2005 & 2006 \\
\hline $\begin{array}{l}\text { Market Capitalisation } \\
\text { In USD (Mumbai Stock Exchange) }\end{array}$ & 110,396 & 131,011 & 279,093 & 387,851 & 553,074 & 818,879 \\
\hline $\begin{array}{l}\text { Trading Volume } \\
\text { In USD (Mumbai and NS Exchange) } \\
\text { Turnover Ratio }\end{array}$ & $\begin{array}{l}249,298 \\
191.4 \\
\end{array}$ & $\begin{array}{l}197,118 \\
165\end{array}$ & $\begin{array}{l}284,802 \\
138.5 \\
\end{array}$ & $\begin{array}{l}379,085 \\
115.5 \\
\end{array}$ & $\begin{array}{l}443,175 \\
93.6\end{array}$ & $\begin{array}{l}638,484 \\
94.4\end{array}$ \\
\hline $\begin{array}{l}\text { S\&P/IFCG Index } \\
\text { Number of Stocks } \\
\text { Share of Market Capitalisation (\%) } \\
\text { Share of Value Traded (\%) } \\
\text { P/E Ratio } \\
\text { P/BV Ratio } \\
\text { Dividend Yield (\%) } \\
\text { Total Return Index } \\
\text { Change in index }(\%)\end{array}$ & $\begin{array}{l}131 \\
74.1 \\
82.5 \\
12.8 \\
1.9 \\
2.4 \\
336.8 \\
-20.1 \\
\end{array}$ & $\begin{array}{l}122 \\
76.4 \\
72.8 \\
15 \\
2 \\
3 \\
365 \\
8.4\end{array}$ & $\begin{array}{l}117 \\
75 \\
74.2 \\
20.9 \\
3.5 \\
1.7 \\
726.3 \\
99.0\end{array}$ & $\begin{array}{l}112 \\
73.7 \\
75.1 \\
18.1 \\
3.3 \\
1.7 \\
911.5 \\
25.5 \\
\end{array}$ & $\begin{array}{l}148 \\
77.9 \\
63.2 \\
19.4 \\
5.2 \\
1.3 \\
1,236.2 \\
35.6 \\
\end{array}$ & $\begin{array}{l}192 \\
81.6 \\
67.2 \\
20.1 \\
4.9 \\
1.1 \\
1,820.9 \\
47.3 \\
\end{array}$ \\
\hline $\begin{array}{l}\text { S\&P/IFCI Index } \\
\text { Number of stocks } \\
\text { P/E Ratio } \\
\text { P/BV Ratio } \\
\text { Dividend Yield (\%) } \\
\text { Total Return Index } \\
\text { Change in index }(\%)\end{array}$ & $\begin{array}{l}79 \\
12.3 \\
2.0 \\
2.0 \\
73.8 \\
-17.8\end{array}$ & $\begin{array}{l}74 \\
15.4 \\
2.6 \\
2.3 \\
81.1 \\
9.9\end{array}$ & $\begin{array}{l}75 \\
20.6 \\
3.9 \\
1.6 \\
147.2 \\
81.5\end{array}$ & $\begin{array}{l}91 \\
18.9 \\
3.7 \\
1.6 \\
180.9 \\
22.9\end{array}$ & $\begin{array}{l}133 \\
20.7 \\
5.5 \\
1.2 \\
245.5 \\
35.7\end{array}$ & $\begin{array}{l}182 \\
20.9 \\
5.3 \\
1.0 \\
365.3 \\
48.8\end{array}$ \\
\hline
\end{tabular}

Source: S\&P - Global Stock Market Factbook (2007) 
Table No. 2

Descriptive Statistics

\begin{tabular}{|c|c|c|c|c|c|c|c|c|c|}
\hline & \multicolumn{3}{|c|}{ World-Return $(\%)$} & \multicolumn{3}{|c|}{ India-Return (\%) } & \multicolumn{3}{|c|}{ NFEI(US\$ Million) } \\
\hline & Full & First & Second & Full & First & Second & Full & First Sub- & Second \\
\hline & Sample & Sub- & Sub- & Sample & Sub- & Sub- & Sample & Sample & Sub- \\
\hline & & Sample & Sample & & Sample & Sample & & & Sample \\
\hline & 2001-07 & 2001-03 & 2004-07 & 2001-07 & 2001-03 & 2004-07 & 2001-07 & 2001-03 & 2004-07 \\
\hline Mean & 0.024 & -0.008 & 0.056 & 0.097 & 0.066 & 0.127 & 23.854 & 13.263 & 34.299 \\
\hline Median & 0.044 & 0.026 & 0.054 & 0.130 & 0.069 & 0.207 & 10.540 & 6.759 & 25.589 \\
\hline Max & 4.713 & 4.713 & 2.095 & 8.615 & 4.833 & 8.615 & 929.225 & 260.935 & 929.225 \\
\hline Min & -3.620 & -3.620 & -2.285 & -11.264 & -5.959 & -11.264 & -791.319 & -87.501 & -791.319 \\
\hline STD & 0.863 & 1.081 & 0.572 & 1.430 & 1.357 & 1.498 & 98.586 & 29.811 & 134.978 \\
\hline Skewness & 0.084 & 0.172 & -0.138 & -0.598 & -0.418 & -0.738 & 0.778 & 2.123 & 0.359 \\
\hline Kurtosis & 5.804 & 4.471 & 3.873 & 8.584 & 5.337 & 10.643 & 21.727 & 12.917 & 12.124 \\
\hline
\end{tabular}

NFEI: Net Flow of Equity Investment

Table No. 3

ADF Test Statistic (2001-07)

\begin{tabular}{|l|ll|ll|}
\hline & Level Data & First Difference & \\
\hline & $\begin{array}{l}\text { With intercept and } \\
\text { no trend }\end{array}$ & $\begin{array}{l}\text { With intercept and } \\
\text { trend }\end{array}$ & $\begin{array}{l}\text { With intercept and } \\
\text { no trend }\end{array}$ & $\begin{array}{l}\text { With intercept } \\
\text { and trend }\end{array}$ \\
\hline First Sample & & & & -24.95822 \\
WLD & -1.779869 & -0.884858 & -24.85539 & -24.45043 \\
IND & 0.791576 & -0.316441 & -24.17118 & -9.777149 \\
NFEI & -0.133744 & -0.808928 & -9.783689 & \\
\hline Second Sample & & & & -23.44495 \\
WLD & -0.072977 & -3.198806 & -23.44198 & -21.40726 \\
IND & 0.473794 & -2.686865 & -21.35502 & -11.09462 \\
NFEI & -1.632084 & -1.876998 & -11.02504 & \\
\hline Critical Value (5\%) & -2.863161 & -3.412651 & & \\
\hline
\end{tabular}


Table No. 4

Cointegration Test

Panel A

\begin{tabular}{|c|c|c|c|c|c|}
\hline No of CEs & Eigenvalue & $\begin{array}{l}\text { Trace } \\
\text { Statistic }\end{array}$ & $\begin{array}{l}5 \text { Percent } \\
\text { Critical Value }\end{array}$ & $\begin{array}{l}\text { Max-Eigen } \\
\text { Statistic }\end{array}$ & $\begin{array}{l}5 \text { Percent } \\
\text { Critical Value }\end{array}$ \\
\hline $\mathrm{r}=0$ & 0.005726 & 5.000873 & 15.41 & 4.484636 & 14.07 \\
\hline$r \leq 1$ & 0.000661 & 0.516237 & 3.76 & 0.516237 & 3.76 \\
\hline
\end{tabular}

Panel B

\begin{tabular}{|c|c|c|c|c|c|}
\hline \multicolumn{6}{|c|}{ WLD and India - Second Sample (2004-07) } \\
\hline & & Trace & 5 Percent & Max-Eigen & 5 Percent \\
\hline No of CEs & Eigenvalue & Statistic & Critical Value & Statistic & Critical Value \\
\hline $\mathrm{r}=0$ & 0.033564 & 27.15915 & 15.41 & 27.07277 & 14.07 \\
\hline$r \leq 1$ & 0.000109 & 0.08638 & 3.76 & 0.08638 & 3.76 \\
\hline
\end{tabular}

Panel C

\begin{tabular}{|c|c|c|c|c|c|}
\hline \multicolumn{6}{|c|}{ WLD, India and NFEI - First Sample (2001-03) } \\
\hline & & Trace & 5 Percent & Max-Eigen & 5 Percent \\
\hline No of CEs & Eigenvalue & Statistic & Critical Value & Statistic & Critical Value \\
\hline $\mathrm{r}=0$ & 0.145137 & 133.8631 & 29.68 & 122.4718 & 20.97 \\
\hline$r \leq 1$ & 0.009571 & 11.39132 & 15.41 & 7.510887 & 14.07 \\
\hline$r \leq 2$ & 0.004956 & 3.880431 & 3.76 & 3.880431 & 3.76 \\
\hline
\end{tabular}

Panel D

\begin{tabular}{|c|c|c|c|c|c|}
\hline \multicolumn{6}{|c|}{ WLD and NFEI - First Sample (2001-03) } \\
\hline & & Trace & 5 Percent & Max-Eigen & 5 Percent \\
\hline No of CEs & Eigenvalue & Statistic & Critical Value & Statistic & Critical Value \\
\hline $\mathrm{r}=0$ & 0.043325 & 36.5416 & 15.41 & 34.59134 & 14.07 \\
\hline$r \leq 1$ & 0.002494 & 1.950257 & 3.76 & 1.950257 & 3.76 \\
\hline
\end{tabular}

Panel E

\begin{tabular}{|c|c|c|c|c|c|}
\hline \multicolumn{6}{|c|}{ WLD, India and NFEI - Second Sample (2004-07) } \\
\hline No of CEs & Eigenvalue & $\begin{array}{l}\text { Trace } \\
\text { Statistic }\end{array}$ & $\begin{array}{l}5 \text { Percent } \\
\text { Critical Value }\end{array}$ & $\begin{array}{l}\text { Max-Eigen } \\
\text { Statistic }\end{array}$ & $\begin{array}{l}5 \text { Percent } \\
\text { Critical Value }\end{array}$ \\
\hline $\mathrm{r}=0$ & 0.034807 & 45.02872 & 29.68 & 28.09377 & 20.97 \\
\hline$r \leq 1$ & 0.020999 & 16.93495 & 15.41 & 16.82989 & 14.07 \\
\hline $\mathrm{r} \leq 2$ & 0.000132 & 0.105051 & 3.76 & 0.105051 & 3.76 \\
\hline
\end{tabular}


Table No. 5

ECT and Granger Causality (2004-07)

\begin{tabular}{lllll}
\hline y granger causes $x$ & WLD & IND & NFEI & ECT $_{\mathrm{t}-1}$ \\
WLD & - & $6.85^{*}$ & $3.07^{*}$ & $-8.73^{*}$ \\
IND & -1.93 & - & 0.29 & $16.98^{*}$ \\
NFEI & 1.37 & $4.47^{*}$ & - & -1.48 \\
\hline
\end{tabular}

* Indicates Significance at 5\% Level

Table No. 6

Variance Decomposition (2004-07)

\begin{tabular}{|c|c|c|c|c|c|c|c|c|c|}
\hline \multicolumn{4}{|l|}{ World } & \multicolumn{3}{|l|}{ India } & \multicolumn{3}{|c|}{ Net Flow of Equity Investment } \\
\hline Period & WLD & IND & NFEI & WLD & IND & NFEI & WLD & IND & NFEI \\
\hline 1 & 100.00 & 0.00 & 0.00 & 16.34 & 83.66 & 0.00 & 5.28 & 8.19 & 86.52 \\
\hline 5 & 88.98 & 10.62 & 0.40 & 47.53 & 50.17 & 2.30 & 7.36 & 11.76 & 80.88 \\
\hline 10 & 88.28 & 11.29 & 0.43 & 59.71 & 37.26 & 3.03 & 7.75 & 12.37 & 79.87 \\
\hline 15 & 88.05 & 11.51 & 0.44 & 65.12 & 31.53 & 3.35 & 7.88 & 12.60 & 79.53 \\
\hline 20 & 87.93 & 11.62 & 0.45 & 68.20 & 28.27 & 3.53 & 7.94 & 12.71 & 79.34 \\
\hline 25 & 87.86 & 11.69 & 0.45 & 70.18 & 26.17 & 3.65 & 7.98 & 12.79 & 79.23 \\
\hline 30 & 87.81 & 11.73 & 0.45 & 71.56 & 24.70 & 3.74 & 8.01 & 12.83 & 79.15 \\
\hline 35 & 87.78 & 11.77 & 0.45 & 72.58 & 23.62 & 3.80 & 8.03 & 12.87 & 79.10 \\
\hline 40 & 87.75 & 11.79 & 0.46 & 73.37 & 22.79 & 3.84 & 8.05 & 12.90 & 79.06 \\
\hline 45 & 87.73 & 11.81 & 0.46 & 73.99 & 22.13 & 3.88 & 8.06 & 12.92 & 79.03 \\
\hline 50 & 87.71 & 11.83 & 0.46 & 74.49 & 21.60 & 3.91 & 8.07 & 12.93 & 79.00 \\
\hline
\end{tabular}

Figure 1

Performance of MSCI Indian Equity Market vs. MSCI World Index (2001-07)

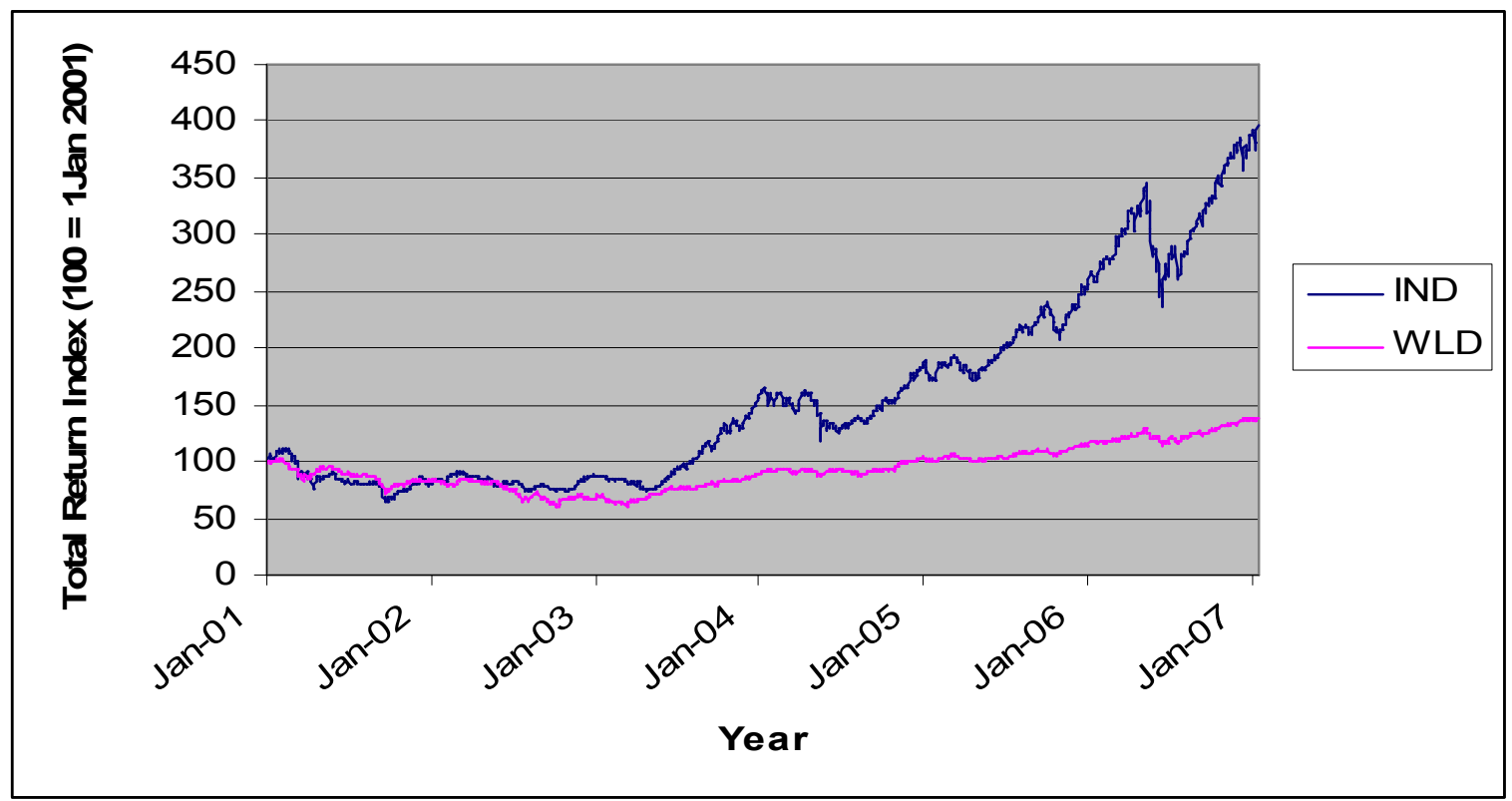


Figure 2

Daily cumulative net foreign equity portfolio investment in India (2001-07)

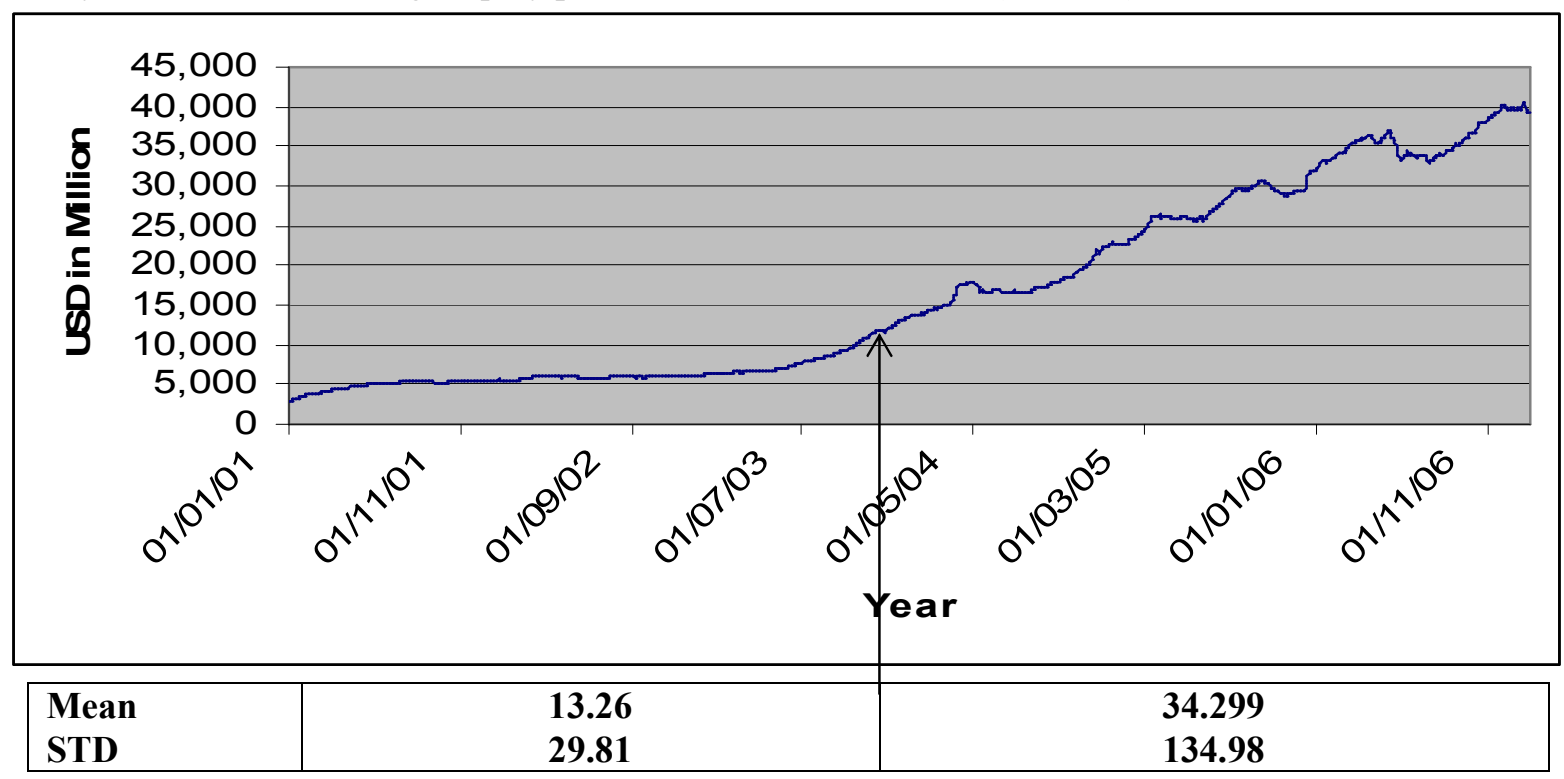


Figure 3

Response of World Equity Return to (2004-07)

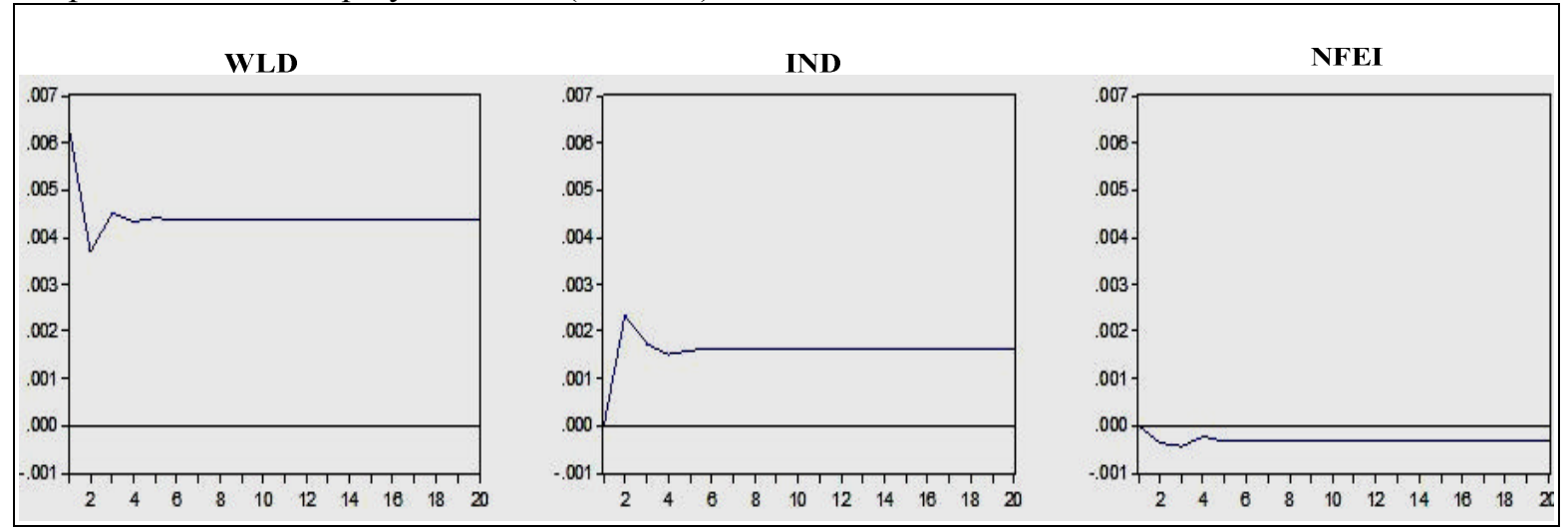

Figure 4

Response of Indian Equity Return to (2004-07)

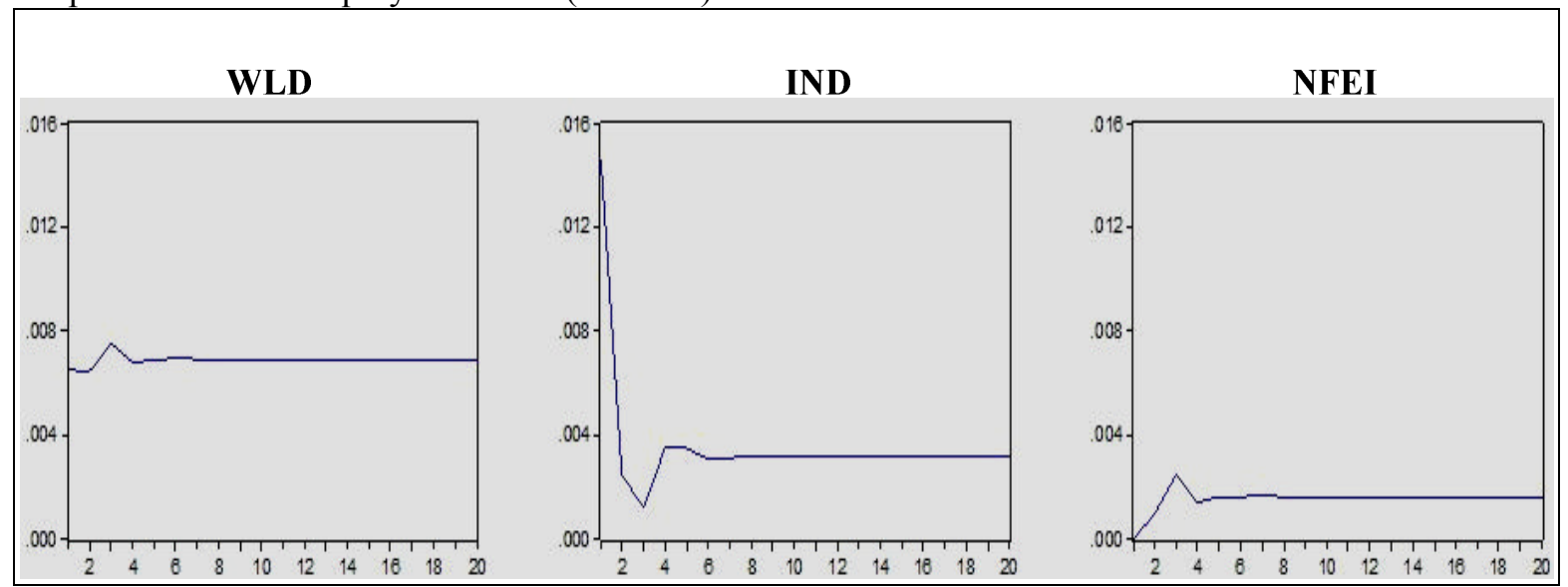

Figure 5

Response of Net Foreign Equity Investment to (2004-07)

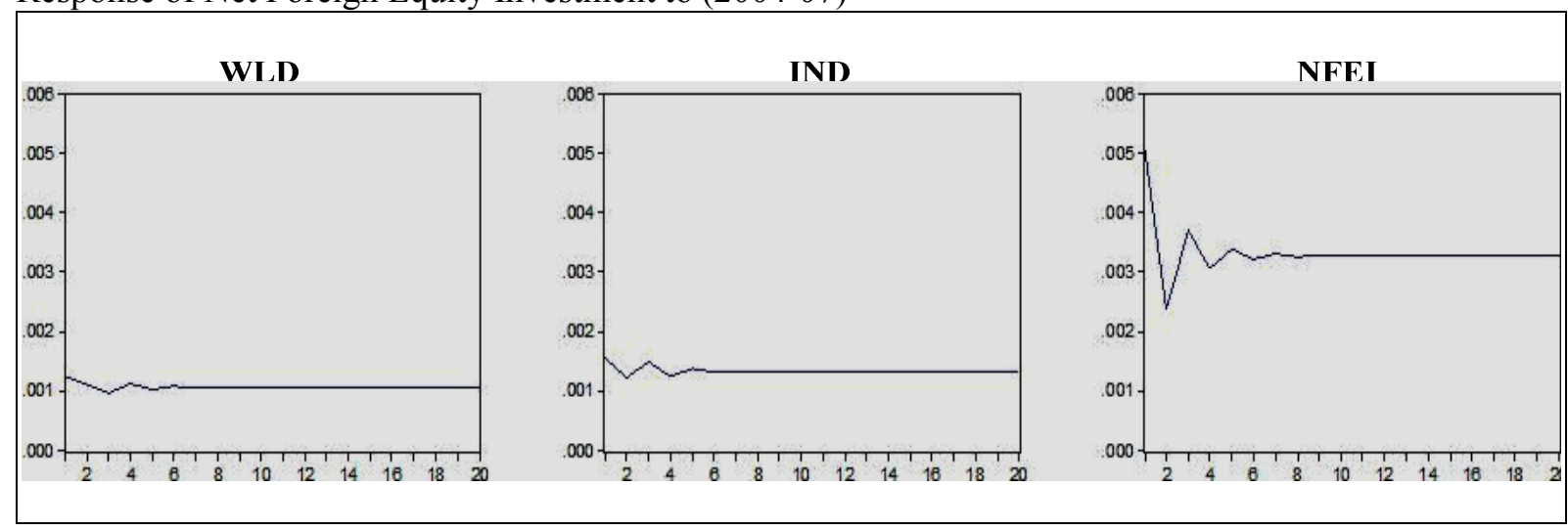

